\title{
Big biotech buys iconic genetics firm
}

\section{Amgen's deal with deCODE Genetics shows value of combined medical and genetic data.}

\section{BY MONYA BAKER}

$\mathrm{M}$ ore than a decade after the sizzle of genomics investments turned to a fizzle, a biotechnology giant is buying one of the field's flagship firms. The announcement on 10 December that Amgen, based in Thousand Oaks, California, will pay US $\$ 415$ million for Iceland's deCODE Genetics, a company with a rocky history, shows that drug developers are again ready to invest in genetic data to find therapeutic targets.

When genomics largely failed to deliver on the promise of new drug targets during the 2000s, many investors, including large drug firms, shed their stakes in companies that dealt with disease-related data and shifted to those with actual compounds in clinical trials. But data and analysis are precisely what deCODE Genetics, based in Reykjavik, has to offer. It has no drug candidates in active clinical trials, and is known chiefly for producing a steady flow of publications that pinpoint genetic culprits - and possible disease mechanisms for conditions including neurodegeneration, cancer, cardiovascular disease and psychosis. For example, deCODE scientists this summer identified a genetic variant that protects against Alzheimer's disease ( $\mathrm{T}$. Jonsson et al. Nature 488, 96-99; 2012).

The key to deCODE's scientific success is its access to a trove of genetic data, genealogies and medical records from some 140,000 Icelanders - roughly half of Iceland's population. Being able to correlate genetic information with Iceland's extensive medical records is one reason why deCODE has made discoveries that other firms have not, says John Bell, a geneticist at the University of Oxford, UK, who chairs a UK advisory group on human genomics. "The genetics bit is the easiest bit; it's the clinical data that has historically been the problem," he says.

The rise of low-cost sequencing and electronic medical records is allowing more information to be extracted from populationgenetics studies, making genomics more attractive to drug companies. Indeed, deCODE's data, technology and expertise will help Amgen to identify which experimental drugs will be most likely to succeed, says Sean Harper, head of research and development at Amgen. Already, two of Amgen's drug candidates - for heart disease and osteoporosis - take aim at protein

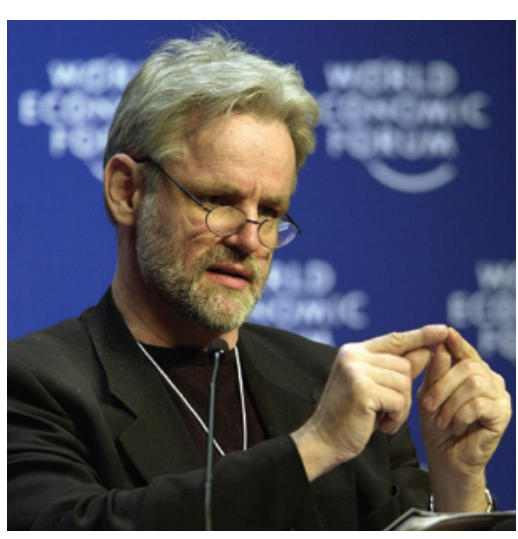

TO THE BRINK AND BACK

Rescued from bankruptcy, Iceland's deCODE Genetics has found new life.

1996 deCODE Genetics founded by Kári Stefánsson (pictured).

2000 deCODE goes public, raising US\$173 million.

\section{4-05 deCODE announces} clinical trials of drugs to prevent heart attacks and asthma.

\section{9 deCODE declares bankruptcy.}

2010 deCODE bought by some of its original investors for \$14 million.

2012 Amgen announces it will acquire deCODE.

targets that were discovered using genetic data, says Harper. "We've become increasingly interested in having more examples of targets discovered or validated by human genetics."

By becoming part of a much bigger biotech firm, deCODE and its chief executive, Kári Stefánsson, may finally be able to fulfil a promise made throughout the company's 16-year history: to use genetic data to benefit patients. Stefánsson says that deCODE can "contribute to more health benefits faster with a company with a proven track record to make therapeutics".

Stefánsson, a gruff man who traces his roots to the Vikings, left a professorship at Harvard Medical School in Boston, Massachusetts, and returned to his homeland to found deCODE in 1996. Like other companies from the genomics boom of the early 2000s, deCODE turned to drug development as a potential source of revenue, launching its own clinical trials in the mid-2000s (see 'To the brink and back'). But the small firm soon racked up huge debts and failed to win investors as Iceland was plunged into the 2008 financial crisis. The company declared bankruptcy in 2009 and was rescued by some of its original investors, who acquired the firm and its assets for around \$14 million and went on to invest another roughly $\$ 45 \mathrm{mil}$ lion. "Even though we are [venture capitalists], it's not just about financial returns," says Terry McGuire, a co-founder of Polaris Venture Partners in Waltham, Massachusetts. "We decided it really was a world treasure."

After the deCODE acquisition, due to be finalized in the next two weeks, Stefánsson will stay on as president of deCODE and become a vice-president at Amgen. He says that deCODE will have no lay-offs and will probably even hire staff. Stefánsson emphasizes that the new ownership will not affect how Icelanders' data are managed. The DNA samples will remain in Iceland and access will be through deCODE, subject to existing privacy-protection policies and oversight by an ethics committee of Icelandic citizens.

Scientists from deCODE are some of the most-cited geneticists, and some researchers worry that as the Icelandic group boosts Amgen's product pipelines, deCODE's leadership in basic research will fade. "deCODE may find it far harder to continue publishing its findings if they're being treated as a potential competitive advantage," says Daniel MacArthur, a geneticist at Massachusetts General Hospital in Boston.

But Harper dismisses such concerns, saying that it is in Amgen's interest to keep deCODE's scientific edge razor sharp. "For us to in some way squelch that creativity would be very shortsighted." Stefánsson is confident that business at deCODE will continue as usual. "I am unafraid, $\rightarrow$ NATURE.COM

The Encyclopedia of

DNA Elements:

nature.com/encode unconcerned and enthusiastic about what is happening," he says. "We will continue to indulge in our discovery orgy." - 